\title{
The Tyrolean early vascular ageing-study (EVA-Tyrol): study protocol for a non- randomized controlled trial
}

\section{Effect of a cardiovascular health promotion program in youth, a prospective cohort study}

Benoît Bernar ${ }^{1}$, Nina Gande ${ }^{2}$, Katharina A. Stock², Anna Staudt², Raimund Pechlaner ${ }^{1}$, Ralf Geiger ${ }^{3,4}$, Andrea Griesmacher ${ }^{5}$, Stefan Kiechl ${ }^{1}$, Michael Knoflach ${ }^{1 *+}$ (D) Ursula Kiechl-Kohlendorfer ${ }^{2 \dagger}$ and for the Early Vascular Aging (EVA) Study Group

\begin{abstract}
Background: According to the World Health Organization, cardiovascular diseases (CVDs) are the leading noncommunicable cause of death. Awareness of the individual risk profile is crucial to implement a healthy lifestyle and prevent CVDs. Multiple studies demonstrated that atherosclerosis, the main cause of CVDs, begins early in life. Therefore, it may be necessary to start prevention programs already in childhood.

Methods: The EVA-Tyrol study is a population-based non-randomized controlled trial that will prospectively enroll 2000 participants from high schools and training companies in North- and East-Tyrol (Austria) and South-Tyrol (Italy). Participants will be assigned to either an intervention $(n=1500)$ or a control $(n=500)$ group. Intervention group participants will be enrolled at the 10th school grade (mean age 15-16 years), undergo two examinations within a two-year interval, with follow-up at the 12th grade (mean ages 17-18 years). Control group participants will be enrolled at the 12th grade (mean age 17-18 years). Medical examination will include anthropometric measurements, comprehensive lifestyle and dietary questionnaires, a fasting blood sample, high-resolution ultrasound of the carotid arteries, and measurement of carotid-femoral pulse wave velocity. Active intervention will consist of (1) enhancing knowledge about CVDs, (2) individual medical counseling based on the results of the baseline examination, (3) an online health promotion tool and (4) involvement of participants in planning and implementation of health promotion projects. Effectiveness of the intervention will be assessed by comparing the proportion subjects with ideal health metrics as defined by the American Heart Association between study groups.

Discussion: This study aims to improve cardiovascular health in Tyrolean adolescents by demonstrating the efficacy of a multi-layer health promotion program and may yield novel insights into the prevalence of vascular risk conditions and mechanisms of early vascular pathologies in adolescents.
\end{abstract}

Trial registration: EVA-Tyrol has been retrospectively registered at clinicaltrials.gov under NCT03929692 since April 29, 2019.

\footnotetext{
* Correspondence: Michael.knoflach@i-med.ac.at

${ }^{\dagger}$ Michael Knoflach and Ursula Kiechl-Kohlendorfer contributed equally to this

work.

${ }^{1}$ Department of Neurology, Medical University of Innsbruck, Anichstrasse 35,

A-6020 Innsbruck, Austria

Full list of author information is available at the end of the article
}

(c) The Author(s). 2020 Open Access This article is distributed under the terms of the Creative Commons Attribution 4.0 International License (http://creativecommons.org/licenses/by/4.0/), which permits unrestricted use, distribution, and

reproduction in any medium, provided you give appropriate credit to the original author(s) and the source, provide a link to the Creative Commons license, and indicate if changes were made. The Creative Commons Public Domain Dedication waiver (http://creativecommons.org/publicdomain/zero/1.0/) applies to the data made available in this article, unless otherwise stated. 


\section{Background}

According to the world health organization (WHO), 17.7 million people died from CVDs in 2015 [1, 2], with ischemic heart disease and stroke accounting for $26.6 \%$ of all deaths worldwide [3]. The Committee on Preventing the Global Epidemic of Cardiovascular Disease recommended that apart from early diagnosis and management of CVDs interventions at 'all stages of life course' should be performed in order to 'promote cardiovascular health by preventing acquisition and augmentation of risk' [4]. Awareness of the individual risk profile and subsequent modification of risk factors and risk behavior are prerequisites for effective prevention. However, it is unclear at which age best to initiate prevention.

While CVDs occur predominately in the elderly, atherosclerosis starts in early life and might even be influenced by fetal and postnatal development. According to the Barker hypothesis, early life factors such as being born preterm or small for gestational age, or impaired fetal growth or inadequate weight gain in the first years of life may predispose to CVDs later in life [5-8]. Histologic necropsy studies found coronary atherosclerotic plaques in $12 \%$ of adolescents and $28 \%$ of young adults [9]. Classical cardiovascular risk factors like smoking, physical inactivity and unhealthy diet are present not only in adults and adolescents but also in the pediatric population [10-12]. In addition, unfavorable health behaviors like sedentary lifestyle, smoking and alcohol consumption may be acquired in late childhood [13-15] and frequently persist in adulthood. Cohort studies have demonstrated the effects of risk factors on early atherosclerotic vessel wall thickening using high-resolution ultrasonography in children, adolescents and young adults [16, 17]. Conversely, a more favorable cardiovascular risk profile in childhood (as defined by the AHA) is associated with a lower aortic intima-media thickness (IMT) and a better aortic elasticity [18], and with a reduced risk of hypertension, metabolic-syndrome and elevated low-density lipoprotein cholesterol in adulthood [19]. Early correction of an unfavorable lifestyle can prevent CVDs in later life [20]. Adverse effects of obesity may be reversed by early weight reduction [20]. In Children, lifestyle and dietary counseling exhibits favorable effects on their cardiovascular risk profile without harmful side-effects $[18,21]$.

In summary, it is well established that cardiovascular risk factors (CVRFs) are related to early vascular ageing and early atherosclerotic wall changes in children and young adults. Promotion of a healthy lifestyle and control of CVRF. In youth presents the opportunity to reverse these changes and prevent persistence of risk conditions into adulthood. The current study will evaluate the efficacy of a defined cardiovascular health promotion program in facilitating risk factor control.

\section{Trial aim and objectives}

The aim of EVA-Tyrol is to promote cardiovascular health in high schools/training companies by an interventional health promotion program and to acquire data on its efficacy in a cohort of Tyrolean adolescents with a mean age of $15-16$ years.

The primary objectives of EVA-Tyrol are:

- To assess health in the Tyrolean youth

- To survey the effect of a multi-layer health promotion program in this age group

- To study the effects of neonatal and childhood weight gain on CVRF in youth

- To assess the effects of being born preterm or small for gestational age on vascular health in youth

- To determine the effects of CVRF on vascular health in youth

- To explore the effects of lifestyle on vascular health in youth

- To establish a serum biobank

\section{Methods and design Study design}

The EVA-study is a non-randomized controlled trial. Two thousand participants will be recruited from high schools and training companies spread over North- and East-Tyrol (Austria) and South-Tyrol (Italy). Study participants will be assigned to i) health intervention group $(n=1500)$ or ii) control group $(n=500)$. For participants included in the intervention group two examinations will be scheduled within a two-year interval between the examinations. Participants will be in the 10th grade (mean age, 15-16 years) at the baseline and in the 12th grade (mean age, 17-18 years) at the follow-up examination. Between the examinations the health intervention program will be offered.

Five hundred participants with a mean age of 17-18 years without participation in a health promotion program will serve as a control group. The prevalence of AHA health metrics in the intervention group will be compared to the prevalence in the control group (Fig. 1).

In addition to health metrics, EVA-Tyrol will evaluate further components and determinants of cardiovascular health of Tyrolean adolescents. In addition, we will collect information on the first 6 years of life including pre-, peri- and postnatal data prospectively documented in the mother-child booklet, the official Austrian pregnancy and early childhood medical record book.

\section{Participants}

\section{Recruitment}

The local education authority (Landesschulrat for Tyrol) will brief all Tyrolean high schools about the project. Subsequently, the schools will be able to apply for study- 


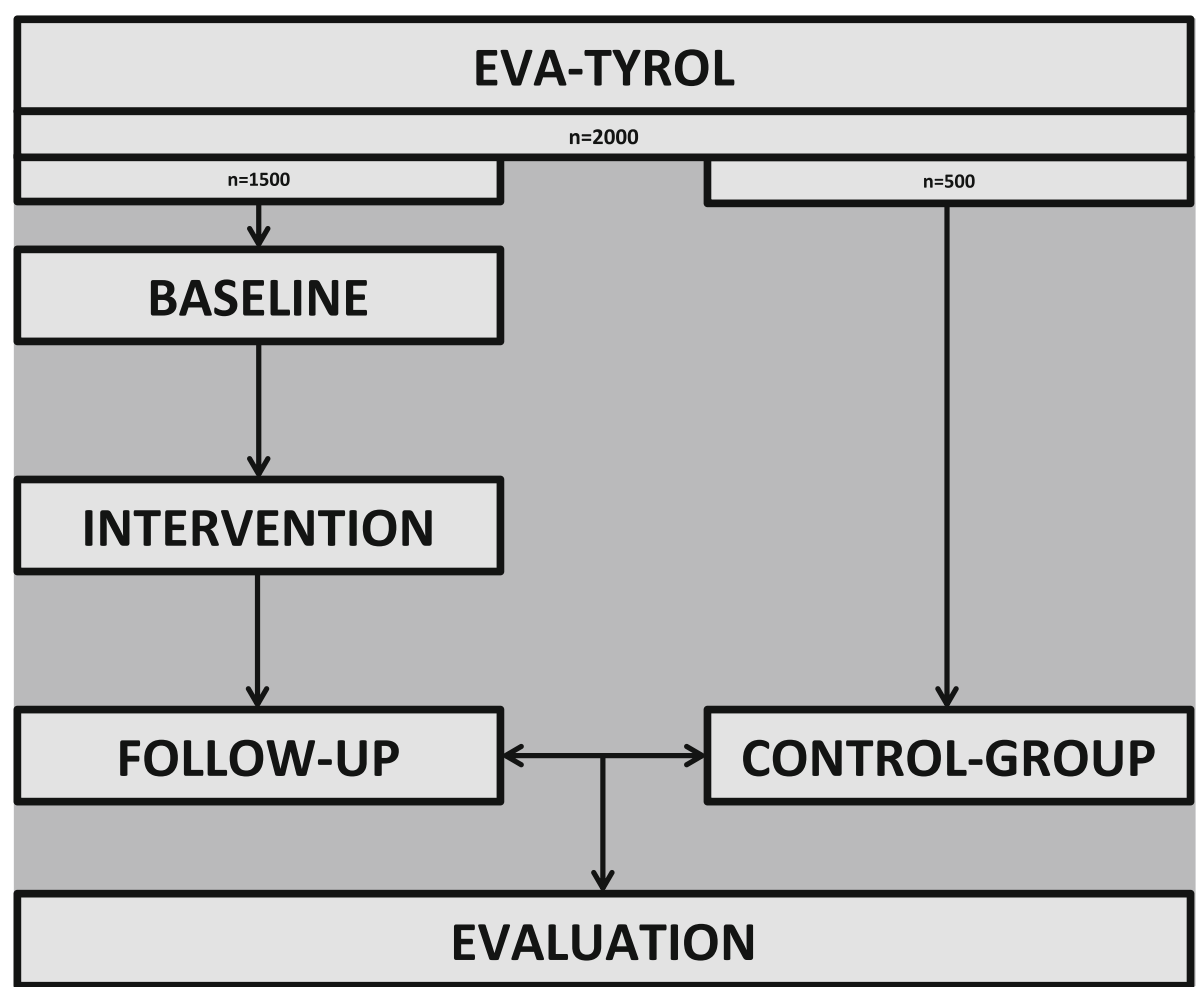

Fig. 1 Schematic illustration of study design

inclusion. In order to ensure a homogenous regional and social distribution, principals of selected schools will be actively encouraged to participate. Schools and training companies will not receive financial compensation for participation. The two study centers will be Innsbruck (Austria) for North and East Tyrol and Bruneck (Italy) for South Tyrol. Moreover, Tyrolean training companies will be invited to participate. For participating schools and companies a project presentation on the background of CVD and concept of CVRF will be offered. Pupils and trainees will be briefed about the study procedure. In addition, a video summarizing study aims and procedures will be shown.

\section{Inclusion criteria}

Participants in the 10th to 12 th grade (mean ages 15-16 at baseline for the intervention group and 17-18 years for the control group) will be enrolled. Informed consent by the participant and, for participants younger than 18 years, their legal representative will be obtained. Consent for inclusion of data from the "mother-child booklet" additional maternal informed consent will be obtained.

Schools and training companies will be randomly assigned to either the intervention or the control group. The examination of the intervention group will start first. Schools will be assigned to either group according to their available schedule. The exact number of participating schools/training companies will depend on the number of participants per school/company.

\section{Exclusion criteria}

None; previous or concurrent diseases are not an exclusion criterion.

\section{Data acquisition}

The study will take place at the schools' or training companies' sites. An overview of the trial procedures is depicted in Fig. 2. Data will be collected by a paper case report form (CRF) and include a self-administered and assisted questionnaire, a structured interview and a series of examinations (blood sampling, high-resolution ultrasound of the carotid arteries, tonometric measurement of carotid-femoral pulse-wave velocity, blood-pressure measurement and anthropometry). Data acquisition will be done by medical doctors assisted by medical students.

\section{Questionnaire}

Table 1 shows the structure of the employed CRF. The CRF is adapted from the Bruneck- [27], ARMY- [16], ARFY- [17] and HBSC (Health Behavior in School Children Study)- [22] studies and organized in three parts: the first part of the CRF is self-administered, the second part has to be completed under group supervision of an MD. The third part is a structured face-to-face questionnaire 


\begin{tabular}{|c|c|c|c|c|c|c|}
\hline & Recruitment & Enrollment & $\begin{array}{c}\text { Day } \\
1\end{array}$ & $\begin{array}{l}\text { Day } \\
3-30 \\
\end{array}$ & $\begin{array}{l}\text { Month } \\
2-23\end{array}$ & $\begin{array}{c}\text { Month } \\
24\end{array}$ \\
\hline $\begin{array}{l}\text { General Health and Study } \\
\text { Information }\end{array}$ & $x$ & & & & & \\
\hline Informed Consent & & $x$ & & & & \\
\hline Fasting blood sample & & & $x$ & & & \\
\hline Questionnaires & & & $x$ & & & \\
\hline $\begin{array}{l}\text { Data extraction mother- } \\
\text { child-booklet }\end{array}$ & & & $x$ & & & \\
\hline $\begin{array}{l}\text { Physical examination } \\
\text { (antropometry, BP) }\end{array}$ & & & $x$ & & & \\
\hline $\begin{array}{l}\text { Ultrasound common } \\
\text { carotid arteries }\end{array}$ & & & $x$ & & & \\
\hline $\begin{array}{l}\text { Carotid-femoral pulse wave } \\
\text { velocity }\end{array}$ & & & $x$ & & & \\
\hline Medical counseling & & & & $x$ & & \\
\hline $\begin{array}{c}\text { Self-assessment tool } \\
\text { (health App and website) }\end{array}$ & & & & & $\mathrm{x}^{*}$ & \\
\hline Health promotion projects & & & & & $\mathrm{x}^{*}$ & \\
\hline $\begin{array}{l}\text { Follow-up examination* } \\
\text { (questionnaire, fasting } \\
\text { blood sample, physical } \\
\text { examination, ultrasound, } \\
\text { pulse wave velocity) }\end{array}$ & & & & & & $x^{*}$ \\
\hline
\end{tabular}

Fig. 2 SPIRIT diagram: Timeframe of EVA-Tyrol

by an MD about the study's main outcome parameters and previous medical history of each participant (Table 1). The family history for diabetes, hypertension or CVDs, is explored separately for each condition and rated as present when at least one first or $2 \mathrm{~s}$ degree relatives became diseased at an early age (women $<65$ years, men $<55$ years).

\section{Mother-child booklet data}

In 1974 the Austrian government introduced a motherchild booklet ("Mutter-Kind Pass") aiming to improve the health of pregnant women and children [31]. It consists of predefined examinations of the mother, the fetus, and the newborn and extends until the age of 6 years. Results of these examinations are documented in a booklet. As the child's continuous financial governmental support is dependent on the completion of all examinations, adherence to the suggested medical examinations is high. Data extracted from the mother-child booklet is shown in Table 2. The Italian mother-child booklet is similar in content except for minor differences in examination intervals.

\section{Physical examination}

Physical examination will be performed by study personnel. Anthropometric measurements will include size and weight as well as waist- and hip-circumference. Blood pressure will be measured three times in the sitting position after $5 \mathrm{~min}$ of rest by a standard digital haemodynamometer (Omron; Omron Healthcare, Lake Forest, Illinois, US) on both arms. Highresolution ultrasound of the carotid arteries will be performed with a portable GE medical Vivid $_{i}$ ultrasound with a linear transducer $12 \mathrm{~L}$ RS probe (both General Electric, GE-Healthcare, Chicago, US). The intima-media thickness (IMT) will be assessed by experienced sonographers from the anterior and posterolateral view. Representative images will be stored digitally and IMT will be measured offline on the stored images on three representative locations in the distal proportion of the common carotid artery of both sides. Carotid-femoral pulse wave velocity and central blood pressure will be calculated as a surrogate for aortic stiffness from simultaneous recording of ten consecutive pulse waves of artefact-free cardiac cycles by applanation tonometry according to the manufacturer's instructions (Complior-Analyze ${ }^{\circ}$, ALAMmedical, Paris, France).

\section{Sample collection and analysis}

Blood samples will be drawn after an overnight fastand will immediately be stored in cooling boxes at 
Table 1 Overview over the EVA-Tyrol questionnaire

\begin{tabular}{|c|c|c|}
\hline \multicolumn{3}{|l|}{ Self-administered } \\
\hline Overall health and life satisfaction, lifestyle factors, social background & 21 items & Health Behaviour in School Children -Study [22] \\
\hline Food habits & 23 items & The Adolescent Food Habits Checklist [23] \\
\hline Nutritional knowledge & 16 items & Turconi score Section E, G and H [24] \\
\hline Participation and perception of health promotion & 12 items & \\
\hline \multicolumn{3}{|l|}{ Assisted } \\
\hline Baecke score for physical activity & 20 items & [25] \\
\hline Score for Allergic Rhinitis & 9 items & {$[26]$} \\
\hline Traffic-Exposure & 3 items & Taken from the ARMY [16] and ARFY [17] studies \\
\hline Food frequency questionnaire & 90 items & Taken from the ARMY [16], ARFY [17] and Bruneck [27] studies \\
\hline \multicolumn{3}{|l|}{ Face-to-face interview } \\
\hline Dietary interview & 7 items & According to the AHA health metrics for youth $[11,28]$ \\
\hline Physical activity & 1 item & $\begin{array}{l}\text { Moderate- and vigorous-intensity activity (minutes per day), } \\
\text { AHA health metrics for youth }[11,28]\end{array}$ \\
\hline Smoking and alcohol consumption & 12 items & Adapted from the Bruneck Study $[27,29]$ \\
\hline $\begin{array}{l}\text { Classical cardiovascular risk-factors and previous } \\
\text { diseases as well as chronic infections. }\end{array}$ & 17 items & $\begin{array}{l}\text { Structured interview for known hypercholesterolemia, diabetes, } \\
\text { hypertonia, diseases of the heart, vasculature, thyroid glands, } \\
\text { liver, lung, known neoplasias, chronic infections of lung, sinuses, } \\
\text { urinary tract, skin or chronic dental infections. }\end{array}$ \\
\hline Family history for CVD & 3 items & $\begin{array}{l}\text { Premature CVDs (women }<65 \text { years, men }<55 \text { years), } \\
\text { hypertension or diabetes in one } 1 \text { st or two } 2 \text { nd } \\
\text { degree relatives. }\end{array}$ \\
\hline Allergies and atopic predisposition & 11 items & $\begin{array}{l}\text { Structured interview for history of allergies, clinical } \\
\text { symptoms and medical therapy. }\end{array}$ \\
\hline Headache history & 8 items & Classification of the international headache society (ICHD-3) [30] \\
\hline Medication use & 9 items & Structured interview for previous and current medication use \\
\hline
\end{tabular}

Table 1 shows an overview of the three parts (self-administered, assisted and face-to-face) of the EVA-Tyrol questionnaire. Left column - topic, middle column number of questions, right column - source/description of questionnaire

approximately $4{ }^{\circ} \mathrm{C}$ before direct transfer to the ISOcertified Central Institute for Medical and Chemical Laboratory Diagnostics of Innsbruck University Hospital. Parameters and measurement methods are detailed in Table 3. Long-term storage of serum and plasma samples will be at $-80^{\circ} \mathrm{C}$. The serum biobank will consist of serum and lithium-heparin plasma, as well as full blood for DNA extraction only for subjects that signed an additional informed consent form.

\section{Cardiovascular health evaluation}

As successfully applied in previous studies [18, 21], healthy lifestyle will be measured by the AHA's seven health metrics (adapted by Lloyd-Jones [11] and Daniels [28]). Every health metric except smoking is categorized into ideal, moderate and poor health as defined in Table 4. Healthy diet is defined by the AHA based on expert opinion and on the dietary approach to stop hypertension (DASH) score. One point is scored for each of the following components: consumption of at least four portions of vegetables and fruits per day, at least three portions of fiber-rich nutriments per day, of fish at least two-times a week, a salt-free or salt-poor diet (less than $1.5 \mathrm{~g} /$ day) and not more than 1 Liter of sugar-rich drinks per week (max. $450 \mathrm{kcal} /$ week) [11].

\section{Intervention}

Our health promotion program is based on (1) enhancing the knowledge about CVDs and related risk factors, (2) medical counseling and discussion of individual risk conditions and lifestyle, (3) providing a self-assessment tool to control and visualize chances in CVD risk conditions and (4) involvement of participants in the planning of health promotion projects.

Our health-promotion program will combine the running health-promotion programs "Gesunde Schule (healthy school)" and "Do-it-yourself!" of the Tyrolean regional medical insurance company (Tiroler Gebietskrankenkasse, TGKK) with the medical examinations of the EVA-Study and health information focusing on CVDs: Potential participants are introduced into the topic of cardiovascular health in a stepwise way. First, adolescents will receive information on the aims of the 
Table 2 Data extracted from the mother-child-booklet

\begin{tabular}{ll}
\hline Mother-child-booklet & \\
\hline Maternal characteristics & Age at pregnancy \\
& Singleton/multiple pregnancy \\
& Body weight and length \\
(begin and end of pregnancy) & Blood pressure (begin and \\
end of pregnancy) & Smoking status (begin and \\
& end of pregnancy) \\
& Pre-existing conditions \\
& (diabetes, hypertension) \\
& Pathological oral glucose \\
& tolerance test \\
Pregnancy complications (yes/no) & Preeclampsia \\
& Hypertension \\
& Proteinuria \\
& Date of birth \\
Characteristics of neonate & Gestational age \\
& Apgar Score \\
& Umbilical blood pH \\
& Mode of birth \\
& Body weight \\
& Body length \\
& Head circumference \\
Data of the child of 8 follow-up & Date of examination \\
moninations at week 4-7, $3-5,7-9,10-14,22-26$, & Body weight \\
$34,46-50$ and 58-62 & Body length \\
& Head circumference \\
& extacted from
\end{tabular}

Table 2 shows an overview of the information extracted from the mother-child-booklet

EVA-project including healthy lifestyle in their school or company (kick-off event). The concept of vascular ageing as a result of continuous accumulation of cardiovascular risks from early life on will be presented orally and by written information material (flyers). The individual visualization of the vessel wall and blood pressure measurement during medical examination will help the adolescents to link this information to their own body. In a second step, individual risk behaviors and laboratory results will be discussed with each participant. In a third step, the summary result from each school/company class will be presented and compared to other schools/ companies.

We will create and provide online tools to promote health among adolescents. A website will be designed with information on healthy lifestyle and will contain an encrypted, password-protected webapp that provides the participants with individual health data. Traffic-lights will be used to represent the seven health metrics defined by the AHA [7, 32]. When adding current personal information on body weight, smoking status or physical activity the colors of the traffic lights will switch from red to green (or vice versa) in order to encourage further healthimprovements. Further health games (e.g. health quiz) will be added to the website.
Participants will have the opportunity to record their own physical activity over 7 days using modern movementtrackers (Move 3, Movisense GmbH, Karlsruhe, Germany). The results of these records will be downloadable from the web-app.

Special health-promotion programs of the TGKK will include behavioral- and circumstance-oriented activities specially designed for each school/company. Representatives of each school/company are invited for an afternoon workshop aiming at health promotion by oral presentations and written information material. The scholars will undergo an interview to define their interests and expectations. The results of these workshops and the interview will pick out the most relevant topics for a tailored health promotion program for each school or company class. Local health-promotion projects will be supervised by the TGKK and presented on the EVA website as a health promotion book.

\section{Outcome measures and statistical analysis}

The primary outcome measure will be the difference in the proportion of each of AHA's seven health metrics in the ideal range between the intervention and the control group.

The secondary outcome measure will be the change in the proportion of AHA's seven health metrics in the ideal range between baseline and follow-up in the intervention group.

Further descriptive and exploratory analysis will focus on the prevalence of unfavorable health behaviors, the prevalence of vascular risk conditions and the change of these factors over age as well as their influence on EVA measured by IMT and the PWV. In addition, the influence of premature birth and early life weight gain (taken from the mother-child-booklet) on obesity and other components of the metabolic syndrome in youth will be explored.

Differences in proportions of the individual health metrics in the ideal range between the intervention and control group (primary outcome parameter) will be analyzed by Chi-squared test. The Prevalence of the individual health metrics in the ideal range in a similar cohort [18] varied from $<5 \%$ for ideal diet, over around $50 \%$ for ideal physical activity to $>80 \%$ for ideal body-mass index. On the basis of a 3:1 intervention to control group split, power analysis indicates that $95 \%$ power can be achieved with a sample size of 2000 to detect differences in proportions between intervention and control group of 3\% (at a control group proportion of 96\%) to $10 \%$ (at a control group proportion of 50\%) [33] .Multivariate analysis will be done by logistic regression.

\section{Principal investigators and study-centers}

Innsbruck: Univ.-Prof. Dr. Ursula Kiechl-Kohlendorfer (Department of Pediatrics II - Neonatology, Medical 
Table 3 'Routine lab parameters and methodology'. HPLC High pressure liquid chromatography, ECLIA Electrochemiluminescenceimmunoassay

\begin{tabular}{|c|c|c|c|c|}
\hline Parameter & Unit & Method & Reagent & Analyzer \\
\hline Glucose & $\mathrm{mg} / \mathrm{dl}$ & Hexokinase method & Roche & Cobas 8000 \\
\hline HbA1c (DCCT/NGSP) & $\%$ & HPLC & Menarini & HA $8180 \mathrm{~T}$ \\
\hline HbA1c (IFCC) & $\mathrm{mmol} / \mathrm{mol}$ & HPLC & Menarini & HA 8180 T \\
\hline Insulin & $\mathrm{mU} / \mathrm{l}$ & ECLIA & Roche & Cobas 8000 \\
\hline Cholesterol & $\mathrm{mg} / \mathrm{dl}$ & Enzymatic color assay & Roche & Cobas 8000 \\
\hline HDL-Cholesterol & $\mathrm{mg} / \mathrm{dl}$ & Enzymatic color assay & Roche & Cobas 8000 \\
\hline LDL-Cholesterol & $\mathrm{mg} / \mathrm{dl}$ & Enzymatic color assay & Roche & Cobas 8000 \\
\hline Triglyceride & $\mathrm{mg} / \mathrm{dl}$ & Enzymatic color assay & Roche & Cobas 8000 \\
\hline Lipoprotein (a) & $\mathrm{nmol} / /$ & Particle-enhanced immunological clouding assay & Roche & Cobas 8000 \\
\hline Total-Homocystein & umol/l & Chemiluminescence microparticle immunoassay & Abbott & Architect \\
\hline Urea & $\mathrm{mg} / \mathrm{dl}$ & Kinetic test with urease and Glutamate dehydrogenase & Roche & Cobas 8000 \\
\hline Creatinine (enzym.-IDMS) & $\mathrm{mg} / \mathrm{dl}$ & Enzymatic color assay & Roche & Cobas 8000 \\
\hline Total-protein & $\mathrm{g} / \mathrm{dl}$ & Biuret test & Roche & Cobas 8000 \\
\hline Uric acid & $\mathrm{mg} / \mathrm{dl}$ & Enzymatic color assay with uricase & Roche & Cobas 8000 \\
\hline Potassium & $\mathrm{mmol} / \mathrm{l}$ & Indirect potentiometry & Roche & Cobas 8000 \\
\hline Calcium & $\mathrm{mmol} / \mathrm{l}$ & Photometric with 5-Nitro-5'-methyl-BAPTA & Roche & Cobas 8000 \\
\hline GOT (ASAT) & $U / l$ & According to IFCC recommendations, though optimized & Roche & Cobas 8000 \\
\hline GPT (ALAT) & $\mathrm{U} / \mathrm{l}$ & According to IFCC recommendations, though optimized & Roche & Cobas 8000 \\
\hline Gamma-GT & $U / l$ & Enzymatic color assay & Roche & Cobas 8000 \\
\hline Creatine kinase & $\mathrm{U} / \mathrm{l}$ & Enzymatic UV-Assay & Roche & Cobas 8000 \\
\hline C-reactive protein & $\mathrm{mg} / \mathrm{dl}$ & Particle-enhanced immunological clouding assay & Roche & Cobas 8000 \\
\hline Ferritin & $u g / l$ & Particle-enhanced immunological clouding assay & Roche & Cobas 8000 \\
\hline TSH & $\mathrm{mU} / \mathrm{l}$ & ECLIA & Roche & Cobas 8000 \\
\hline Free thyroxine (FT4) & $\mathrm{pmol} / \mathrm{l}$ & ECLIA & Roche & Cobas 8000 \\
\hline Thyroglobulin & ug/l & ECLIA & Roche & Cobas 8000 \\
\hline Thyroglobulin-Antibodies & $\mathrm{kU} / \mathrm{l}$ & ECLIA & Roche & Cobas 8000 \\
\hline ESR after $1 \mathrm{~h}$ & $\mathrm{~mm} / \mathrm{h}$ & Westergren-Method & Mechatronics & Starrsed Auto Compact \\
\hline Leukocytes & $\mathrm{G} / \mathrm{l}$ & Biofluorescence/flow cytometry & Sysmex & $X E-5000$ \\
\hline Absolute number of Neutrophiles & $\mathrm{G} / \mathrm{l}$ & Biofluorescence/flow cytometry & Sysmex & $X E-5000$ \\
\hline Erythrocytes & $T / /$ & Impedance method & Sysmex & $X E-5000$ \\
\hline Haemoglobin & $g / l$ & Photocolorimetric & Sysmex & $X E-5000$ \\
\hline Hematocrit & $|/|$ & Impedance method & Sysmex & $X E-5000$ \\
\hline Platelets & $\mathrm{G} / \mathrm{l}$ & Impedance method & Sysmex & $X E-5000$ \\
\hline $\mathrm{MCH}$ & $\mathrm{pg}$ & Calculated & Sysmex & $X E-5000$ \\
\hline $\mathrm{MCHC}$ & $g / l$ & Calculated & Sysmex & XE-5000 \\
\hline MCV & $\mathrm{fl}$ & Calculated & Sysmex & $X E-5000$ \\
\hline Erythrocyte-distributional width & $\%$ & Calculated & Sysmex & $X E-5000$ \\
\hline Band neutrophiles & $\%$ & Manual microscopy & manual & Light microscopy \\
\hline Segmented neutrophiles & $\%$ & Biofluorescence/flow cytometry and light microscopy & Sysmex & $X E-5000$ \\
\hline Lymphocytes & $\%$ & Biofluorescence/flow cytometry and light microscopy & Sysmex & $X E-5000$ \\
\hline Lymphocytes & $\mathrm{G} / \mathrm{l}$ & Biofluorescence/flow cytometry and light microscopy & Sysmex & $X E-5000$ \\
\hline Monocytes & $\%$ & Biofluorescence/flow cytometry and light microscopy & Sysmex & XE-5000 \\
\hline Eosinophils & $\%$ & Biofluorescence/flow cytometry and light microscopy & Sysmex & $X E-5000$ \\
\hline
\end{tabular}


Table 3 'Routine lab parameters and methodology'. HPLC High pressure liquid chromatography, ECLIA Electrochemiluminescenceimmunoassay (Continued)

\begin{tabular}{|c|c|c|c|c|}
\hline Parameter & Unit & Method & Reagent & Analyzer \\
\hline Basophils & $\%$ & Biofluorescence/flow cytometry and light microscopy & Sysmex & $X E-5000$ \\
\hline Plasma cells & $\%$ & Manual microscopy & Manual & Light microscopy \\
\hline Folic acid & $\mu g / l$ & Competitive binding assay & Roche & Cobas 8000 \\
\hline Vitamin B12 & $\mathrm{pmol} / \mathrm{l}$ & ECLIA & Roche & Cobas 8000 \\
\hline
\end{tabular}

University of Innsbruck, Austria), Assoc.-Prof. Priv.-Doz. Dr. Michael Knoflach (Department of Neurology, Medical University of Innsbruck, Austria).

Bruneck: Univ. -Prof. Dr. Ralf Geiger (Azienda Sanitaria dell'Alto Adige, Hospital of Bruneck, Deptartment of Paediatrics and Department of Pediatrics III - Cardiology, Medical University of Innsbruck, Austria).

\section{Availability of data and materials}

Anonymized data can be shared in academic cooperations. Request for data can be addressed to the principal investigators with an appropriate research question.

\section{Discussion}

The EVA-Tyrol study is a large-scale research and prevention program targeting cardiovascular healthpromotion in adolescents. The planed 2000 participants will represent about $5 \%$ of the Tyrolean population at that age and will allow in-depth insights into vascular risk profile and vascular health of a representative Middle European population. The health promotion program used in our trial could realistically be continued at low costs outside the academic study setting. Our study explores novel grounds, as, even though numerous health promotion programs are targeted to the youth, few did prove efficacy. The STRIP study conducted in Turku, Finland, was able to increase the number of ideal cardiovascular health metrics by accompanying children with dietary and later smoking prevention counselling continuously between the age of 7 month and 20 years. Also, dietary counseling of pre-pubertal children with elevated LDL Cholesterol and their parents effectively reduced LDL Cholesterol [34]. However, other health promotion programs for adolescents were less successful [32, 35]. A recent meta-analysis of 30 studies aiming at improving physical activity in children and adolescents could demonstrate only a modest effect of various interventions [35]. In contrast to our study all these interventions focused on a single health behavior and did not provide comprehensive health counseling on multiple cardiovascular risk factors and behaviors.

The descriptive analysis of the EVA-Tyrol study will substantially enhance our understanding of the distribution of vascular risk behaviors and risk factors in subjects with varying social backgrounds (school types, apprentices) as well as sex and age groups and will help to better focus future health promotion programs.

Furthermore, the EVA-Tyrol cohort will allow to explore mechanisms of early vascular ageing by using well-defined surrogate parameters for vascular health (IMT and PWV) and analyze their association with cardiovascular risk factors and health behaviors. Highquality information from the "mother-child booklet" will elucidate the impact of early life weight gain on adolescent vascular health.

Table 4 'Seven AHA health metrics'

\begin{tabular}{|c|c|c|c|}
\hline Health behavior goal: & Poor & Moderate & Ideal health \\
\hline Smoking-habits & Smoked in the last 30 days & - & $\begin{array}{l}\text { Never smoked, never smoked a } \\
\text { whole cigarette }\end{array}$ \\
\hline Body-Mass-Index & >95th percentile & 85-95th percentile & $<85$ th percentile \\
\hline Physical activity & None & $\begin{array}{l}<60 \text { min moderate or intensive } \\
\text { physical activity per day }\end{array}$ & $\begin{array}{l}\geq 60 \text { min moderate or intensive } \\
\text { physical activity per day }\end{array}$ \\
\hline Healthy diet & 0-1 components & 2-3 components & 4-5 components \\
\hline Total-cholesterol & $\geq 200 \mathrm{mg} / \mathrm{dL}$ & $170-199$ mg/dL & $<170 \mathrm{mg} / \mathrm{dL}$ \\
\hline Blood pressure & >95th percentile & $\begin{array}{l}90-95 \text { th percentile or } \geq 120 \text { systolic } \\
\text { or } \geq 80 \text { diastolic }\end{array}$ & $<90$ th percentile \\
\hline Fasting blood sugar & $\geq 126 \mathrm{mg} / \mathrm{dL}$ & $100-125$ mg/dL & $<100 \mathrm{mg} / \mathrm{dL}$ \\
\hline
\end{tabular}




\section{Abbreviations}

AHA: American heart association; COMET: Competence centers for excellent technologies; CRF: Case report form; ctc: Clinical trial center; CVD: Cardiovascular diseases; CVRF: Cardiovascular risk-factors; Dash: Dietary approach to stop hypertension;

ECLIA: Electrochemiluminescenceimmunoassay; EVA: Early vascular ageing: FFG: Austrian Research Promotion Agency; HPLC: High pressure liquid chromatography; IHS: International headache society; IMT: Intima-media thickness; MD: Medical doctor; NCD: Non-communicable diseases; PI: Principle investigator; PWV: Pulse wave velocity; TGKK: Tiroler Gebietskrankenkasse $=$ Tyrolean regional medical insurance VASCage: Research Center of Excellence in vascular ageing - Tyrol

\section{Acknowledgements}

Early Vascular Aging (EVA) Study Group consists of the following collaborating authors:

Mandy, Asare, Department of Neurology, Medical University of Innsbruck, Innsbruck, Austria

Manuela, Bock-Bartl, Department of Pediatrics II (Neonatology), Medical University of Innsbruck, Innsbruck, Austria

Maximilian, Bohl, Department of Neurology, Medical University of Innsbruck, Innsbruck, Austria

Christina, Burger, Department of Pediatrics II (Neonatology), Medica

University of Innsbruck, Innsbruck, Austria

Gregor, Brössner, Department of Neurology, Medical University of Innsbruck, Innsbruck, Austria

Tatjana, Heisinger, Department of Pediatrics II (Neonatology), Medical

University of Innsbruck, Innsbruck, Austria

Christoph, Hochmayr, Department of Pediatrics II (Neonatology), Medical

University of Innsbruck, Innsbruck, Austria

Julia, Klingenschmid, Department of Pediatrics II (Neonatology), Medical

University of Innsbruck, Innsbruck, Austria.

Martina, Kothmayer, Department of Pediatrics II (Neonatology), Medical

University of Innsbruck, Innsbruck, Austria

Julia, Marxer, Department of Pediatrics II (Neonatology), Medical University of Innsbruck, Innsbruck, Austria

Raimund, Pechlaner, Department of Neurology, Medical University of Innsbruck, Innsbruck, Austria

Maximilian, Pircher, Department of Pediatrics II (Neonatology), Medical University of Innsbruck, Innsbruck, Austria

Carmen, Reiter, Department of Pediatrics II (Neonatology), Medical University of Innsbruck, Innsbruck, Austria

Sophia J, Kiechl, Department of Neurology, Medical University of Innsbruck, Innsbruck, Austria

Bernhard, Winder, Department of Pediatrics II (Neonatology), Medical

University of Innsbruck, Innsbruck, Austria

\section{Authors' contributions}

$\mathrm{NG}, \mathrm{KS}, \mathrm{AS}$ (PhD-students) and RP (scientific collaborator) are involved in the EVA-Tyrol-study and contributed to the preparation and detailed elaboration of the study-protocol and the linguistical elaboration of this publication. RG is responsible for the implementation of the EVA-Tyrol-study in Bruneck (South-Tyrol) and is the principal investigator in Bruneck. AG participated in the elaboration and implementation of the laboratory-parameters surveyed in the EVA-Tyrol-study and will be responsible for the correctness of the laboratory-results. SK is the VASCage's principal investigator and is responsible for the project's funding and the statistical elaboration of our studyprotocol. BB is PhD-student in the EVA-Tyrol-Study and elaborated the present manuscript and was involved in the implementation of the ICHD. UK and MK contributed equally to the elaboration of the study protocol, they are principal investigators in Tyrol (Austria), are EVA-Tyrol's project directors and further more are supervisors of the medical- and PhD-students involved in the EVA-Tyrol-study. All authors read and approved the final manuscript.

\section{Funding}

EVA Tyrol is financially supported by the excellence initiative (Competence Centers for Excellent Technologies-COMET) of the Austrian Research Promotion Agency FFG: "Research Center of Excellence in Vascular Ageing-Tyrol, VASCage" (K Project No. 843536) funded by BMVIT, BMWFW, Wirtschaftsagentur Wien, and Standortagentur Tirol. The funding body had no role in the design of the study, collection, analysis and interpretation of data or in writing the manuscript.

\section{Availability of data and materials}

Request for data shall be addressed to the corresponding authors.

\section{Ethics approval and consent to participate}

Informed consent has to be approved and signed by the participant and by the legal representative if necessary (under the age of 18 years). For the inclusion of data of the "mother-child booklet" an additional maternal informed consent will be necessary.

The consent-form, as well as the complete EVA-Tyrol-Study, has been approved by the ethics-committee of the medical university Innsbruck (AN2015-0005 345/4.13), in order to GCP and the declaration of Helsinki. Innrain 43

6020-Innsbruck

Austria

Phone: + 43 (0) 512/504-25444

Contact: Mag. David Bachler

\section{Consent for publication}

Not applicable.

\section{Competing interests}

The authors declare that they have no competing interests.

\section{Author details}

${ }^{1}$ Department of Neurology, Medical University of Innsbruck, Anichstrasse 35, A-6020 Innsbruck, Austria. ${ }^{2}$ Department of Pediatrics II, Medical University of Innsbruck, Anichstrasse 35, A-6020 Innsbruck, Austria. ${ }^{3}$ Department of Pediatrics III, Medical University of Innsbruck, Anichstrasse 35, A-6020 Innsbruck, Austria. ${ }^{4}$ Department of Pediatrics, Bruneck Hospital, Bruneck, Italy. ${ }^{5}$ Central Institute of Clinical Chemistry and Laboratory Medicine (ZIMCL), Medical University of Innsbruck, Anichstrasse 35, A-6020 Innsbruck, Austria.

Received: 26 July 2019 Accepted: 22 January 2020

Published online: 05 February 2020

\section{References}

1. World Health Organization (WHO). Fact sheet: "Cardiovascular diseases". 2018 URL: http://who.int/mediacentre/factsheets/fs317/en/.

2. World Health Organization (WHO). Mainpage: "Cardiovascular diseases (CVDs)".2018. URL: http://who.int/cardiovascular_diseases/en/.

3. World Health Organization (WHO). Fact sheet: "The top 10 causes of death" 2018 URL: http://www.who.int/en/news-room/fact-sheets/detail/the-top-10causes-of-death.

4. Institute of Medicine. Promoting Cardiovascular Health in the Developing World: A Critical Challenge to Achieve Global Health; chapter 5 reducing the burden of cardiovascular disease: Intervention strategies: The National Academies Press; 2010. https://doi.org/10.17226/12815.

5. Barker DJ, Osmond C, Law CM. The intrauterine and early postnatal origins of cardiovascular disease and chronic bronchitis. J Epidemiol Community Health. 1989:43:237-40.

6. Singhal A, Cole TJ, Fewtrell M, Kennedy K, Stephenson T, Elias-Jones A, Lucas A. Promotion of faster weight gain in infants born small for gestational age: is there an adverse effect on later blood pressure? Circulation. 2007;115(2):213-20.

7. Law CM, Shiell AW, Newsome CA, Syddall HE, Shinebourne EA, Fayers PM, Martyn CN, De Swiet M. Fetal, infant, and childhood growth and adult blood pressure: a longitudinal study from birth to 22 years of age. Circulation. 2002;105(9):1088-92.

8. Posod A, Odri Komazec I, Kager K, Pupp Peglow U, Griesmaier E, Schermer E, Würtinger $P$, Baumgartner D, Kiechl-Kohlendorfer U. Former very preterm infants show an unfavorable cardiovascular risk profile at a preschool age. PLoS One. 2016;11(12):e0168162.

9. Velican D, Velican C. Atherosclerotic involvement of the coronary arteries of adolescents and young adults. Atherosclerosis. 1980;36(4):449-60.

10. World Health Organization (WHO). Published by the World Health Organization in collaboration with the World Heart Federation and the World Stroke Organization. In: Mendis S, Puska P, Norrving B, editors. Global Atlas on cardiovascular disease prevention and control. Section A What are cardiovascular diseases (CVDs)? http:// whqlibdoc.who.int/publications/2011/9789241564373_eng.pdf; 2018. 
11. Lloyd-Jones DM, Hong Y, Labarthe D, Mozaffarian D, Appel L, Van Horn L, Greenlund K, Daniels S, Nichol G, Tomaselli GF, Arnett DK, Fonarow GC, Ho PM, Lauer MS, Masoudi FA, Robertson RM, Roger V, Schwamm LH, Sorlie P, Yancy CW, Rosamond WD, American Heart Association Strategic Planning Task Force and Statistics Committee. Defining and Setting National Goals for Cardiovascular Health Promotion and Disease Reduction. The American Heart Association's Strategic Impact Goal Through 2020 and Beyond. Circulation. 2010;121(4):586-613.

12. Go AS, Mozaffarian D, Roger VL, Benjamin EJ, Berry JD, Blaha MJ, Dai S, Ford ES, Fox CS, Franco S, Fullerton HJ, Gillespie C, Hailpern SM, Heit JA, Howard VJ, Huffman MD, Judd SE, Kissela BM, Kittner SJ, Lackland DT, Lichtman JH, Lisabeth LD, Mackey RH, Magid DJ, Marcus GM, Marelli A, Matchar DB, DK MG, Mohler ER 3rd, Moy CS, Mussolino ME, Neumar RW, Nichol G, Pandey DK, Paynter NP, Reeves MJ, Sorlie PD, Stein J, Towfighi A, Turan TN, Virani SS, Wong ND, Woo D, Turner MB, American Heart Association Statistics Committee and Stroke Statistics Subcommittee. Executive Summary: Heart Disease and Stroke Statistics-2014 Update; A Report from the American Heart Association. Circulation. 2014;129(3):399-410.

13. Health Behavior in School-aged Children (HBSC). HBSC Physical activity focus group. Factsheet: "Physical activity". 2019. http://www.hbsc.org/ publications/factsheets/Physical-Activity-english.pdf.

14. Health Behavior in School-aged Children (HBSC). HBSC Risk behaviours focus group. Factsheet: "Tobacco". 2019. http://www.hbsc.org/publications/ factsheets/Tobacco-english.pdf.

15. Health Behavior in School-aged Children (HBSC), HBSC Risk behaviours focus group. Factsheet: "Alcohol". 2019. http://www.hbsc.org/publications/ factsheets/Alcohol-english.pdf.

16. Knoflach M, Kiechl S, Kind M, Said M, Sief R, Gisinger M, van der Zee R, Gaston $\mathrm{H}$, Jarosch E, Willeit J, Wick G. Cardiovascular risk factors and atherosclerosis in young males: ARMY study (atherosclerosis risk-factors in male youngsters). Circulation. 2003;108(9):1064-9.

17. Knoflach M, Kiechl S, Penz D, Zangerle A, Schmidauer C, Rossmann A, Shingh M, Spallek R, Griesmacher A, Bernhard D, Robatscher P, Buchberger W, Draxl W, Willeit J, Wick G. Cardiovascular risk factors and atherosclerosis in young women: atherosclerosis risk factors in female youngsters (ARFY study). Stroke. 2009;40(4):1063-9.

18. Pahkala K, Hietalampi H, Laitinen TT, Viikari JS, Rönnemaa T, Niinikoski H, Lagström H, Talvia S, Jula A, Heinonen OJ, Juonala M, Simell O, Raitakari OT. Ideal cardiovascular health in adolescence: effect of lifestyle intervention and association with vascular intima-media thickness and elasticity (the special Turku coronary risk factor intervention project for children [STRIP] study). Circulation. 2013;127(21):2088-96.

19. Laitinen TT, Pahkala K, Magnussen CG, Viikari JS, Oikonen M, Taittonen L, Mikkilä V, Jokinen E, Hutri-Kähönen N, Laitinen T, Kähönen M, Lehtimäki T, Raitakari OT, Juonala M. Ideal cardiovascular health in childhood and cardiometabolic outcomes in adulthood: the cardiovascular risk in young Finns study. Circulation. 2012;125(16):1971-8.

20. Juonala M, Magnussen CG, Berenson GS, Venn A, Burns TL, Sabin MA, Srinivasan SR, Daniels SR, Davis PH, Chen W, Sun C, Cheung M, Viikari JS, Dwyer T, Raitakari OT. Childhood adiposity, adult adiposity, and cardiovascular risk factors. N Engl J Med. 2011;365(20):1876-85.

21. Simell $O$, Niinikoski $H$, Rönnemaa $T$, Raitakari $O T$, Lagström $H$, Laurinen $M$, Aromaa M, Hakala P, Jula A, Jokinen E, Välimäki I, Viikari J, STRIP Study Group. Cohort profile: the STRIP study (special Turku coronary risk factor intervention project), an infancy-onset dietary and life-style intervention trial. Int J Epidemiol. 2009;38(3):650-5.

22. Health Behavior in School-aged Children (HBSC). WHO Library Cataloguing in Publication Data. International Report from the 2001/2002 survey, Young people's health in context. Edited by Candace Currie et al. ISBN 928901372 9. (Last 07.01.2019). URL: http://www.euro.who.int/_data/assets/pdf_file/ 0008/110231/e82923.pdf.

23. Johnson F, Wardle J, Griffith J. The adolescent food habits checklist: reliability and validity of a measure of healthy eating behaviour in adolescents. Eur J Clin Nutr. 2002;56(7):644-9.

24. Turconi G, Celsa M, Rezzani C, Biino G, Sartirana MA, Roggi C. Reliability of a dietary questionnaire on food habits, eating behaviour and nutritional knowledge of adolescents. Section E, G and H. Eur J Clin Nutr. 2003;57(6):753-63.

25. Baecke JA, Burema J, Frijters ER. A short questionnaire for the measurement of habitual physical activity in epidemiological studies. Am J Clin Nutr. 1982; 36(5):936-42.
26. Annesi-Maesano I, Didier A, Klossek M, Chanal I, Moreau D, Bousquet J. The score for allergic rhinitis (SFAR) a simple and valid assessment method in population studies. Allergy. 2002;57(2):107-14.

27. Kiechl S, Pechlaner R, Willeit $P$, Notdurfter M, Paulweber B, Willeit K, Werner P, Ruckenstuhl C, Iglseder B, Weger S, Mairhofer B, Gartner M, Kedenko L, Chmelikova M, Stekovic S, Stuppner H, Oberhollenzer F, Kroemer G, Mayr M, Eisenberg T, Tilg H, Madeo F, Willeit J. Higher spermidine intake is linked to lower mortality: a prospective population-based study. Am J Clin Nutr. 2018; 108(2):371-80.

28. Daniels SR, Pratt CA, Hayman LL. Reduction of risk for cardiovascular disease in children and adolescents. Circulation. 2011;124(15):1673-86.

29. Willeit J, Kiechl S, Oberhollenzer F, Rungger G, Egger G, Bonora E, Mitterer M, Muggeo M. Distinct risk profiles of early and advanced atherosclerosis: prospective results from the Bruneck study. Arterioscler Thromb Vasc Biol. 2000;20(2):529-37.

30. International Headache Society. The international classification of headache disorders, 3rd edition. Cephalalgia. 2018;38(1):1-211.

31. Bundes Ministerium für Gesundheit und Familie, Österreich. Mutter-KindPass. 2019 URL: https://www.sozialministerium.at/site/Gesundheit/ Gesundheitsfoerderung/Eltern_und_Kind/Mutter_Kind_Pass.

32. Lubans DR, Lubans DR, Morgan PJ, Okely AD, Dewar D, Collins CE, Batterham M, Callister R, Plotnikoff RC. Preventing obesity among adolescent girls: one-year outcomes of the nutrition and enjoyable activity for teen girls (NEAT girls) cluster randomized controlled trial. Arch Pediatr Adolesc Med. 2012;166(9):821-7.

33. Cohen J. Statistical power analysis for the behavioral sciences, vol. ISBN-13. 2nd ed. Hillsdale: Lawrence Erlbaum; 1988. p. 978-0805802832.

34. Obarzanek E, Kimm SY, Barton BA, Van Horn LL, Kwiterovich PO Jr, SimonsMorton DG, Hunsberger SA, Lasser NL, Robson AM, Franklin FA Jr, Lauer RM, Stevens VJ, Friedman LA, Dorgan JF, Greenlick MR, DISC Collaborative research group. Long-term safety and efficacy of a cholesterol-lowering diet in children with elevated low-density lipoprotein cholesterol: seven-year results of the Dietary Intervention Study in Children (DISC). Pediatrics. 2001; 107(2):256-64.

35. Metcalf B, Henley W, Wilkin T. Effectiveness of intervention on physical activity of children: systematic review and meta-analysis of controlled trials with objectively measured outcomes (EarlyBird 54). BMJ. 2012;345:e5888.

\section{Publisher's Note}

Springer Nature remains neutral with regard to jurisdictional claims in published maps and institutional affiliations.

Ready to submit your research? Choose BMC and benefit from:

- fast, convenient online submission

- thorough peer review by experienced researchers in your field

- rapid publication on acceptance

- support for research data, including large and complex data types

- gold Open Access which fosters wider collaboration and increased citations

- maximum visibility for your research: over $100 \mathrm{M}$ website views per year

At BMC, research is always in progress.

Learn more biomedcentral.com/submissions 